\title{
Budget Rules and Fiscal Policy: Ten Lessons from Theory and Evidence
}

\author{
Alan J. Auerbach \\ University of California, Berkeley
}

November, 2012

This paper will be presented at a conference on Government Debt in Democracies: Causes, Effects, and Limits, Berlin, November 30-December 1, 2012. 


\section{Introduction}

Spurred most recently by developments within the Eurozone, there has been considerable research and discussion over the years about the potential role of fiscal rules in supporting better economic outcomes; the design, implementation and enforcement, of such rules; and the prospects for alternative fiscal and political institutions to promote the objectives to which fiscal rules are typically targeted. This paper provides an overview of some of the findings that this research and unfolding events have brought forward, organized in the form of ten lessons that can be learned from accumulating theory and evidence. After presenting these lessons, I briefly discuss their implications and offer some conclusions.

\section{Ten Lessons}

\section{Budget Rules Can Have an Impact on Fiscal Policies and the Economy}

Perhaps the most relevant question regarding fiscal rules is whether they are likely to have any impact. At first blush, this would seem to be a silly question, as rules are designed to restrict fiscal policy choices. But there are a number of potential reasons why fiscal rules might have a limited impact. First, the rules may simply not be enforced and therefore impose no limits on fiscal policy choices. Second, to the extent that they lack permanence, the rules' existence may be merely a reflection of intended policy. That is, a government that is planning to increase fiscal discipline may promulgate fiscal rules consistent with these plans, and maintain the rules only as long as policy remains consistent with them. In such a case, fiscal rules and fiscal discipline would be coincident, but the rules themselves would have no independent impact on fiscal policy choices. Third, it might be possible to adhere to the rules while 
circumventing their stated intent. For example, a rule imposing caps on direct spending might be side-stepped using tax expenditures; a rule limiting current government budget deficits could be overcome by fiscal expansions for which accounting conventions record only future deficits. In such cases, there might be accounting responses to the fiscal rules, but real policies would be unaffected.

Some evidence appears to support the futility hypothesis. For example, to evaluate the effects of the Eurozone's Maastricht Treaty and the Stability and Growth Pact (SGP), Galí and Perrotti (2003) estimate fiscal rules for the discretionary budget deficit over the period 19802002, using data on EMU countries and control groups of non-EMU EU countries and other nonEU OECD countries. Breaking down the period into pre-Maastricht (1980-91) and postMaastricht (1992-2002) subperiods, they find that discretionary fiscal policy in EMU countries, as measured by the responsiveness of the cyclically adjusted deficit to the output gap, became more countercyclical after the introduction of the budget rules. These results may indicate that the SGP had no impact on the fiscal activism of individual countries; this would not be shocking finding, given various episodes after 2002 during which deviations from the stated rules occurred.

But some care is also needed in interpreting the paper's findings, because changes in cyclically adjusted deficits do not necessarily track actual policy changes very closely. As discussed in Auerbach (2003), there are a variety of factors that can affect the cyclically adjusted surplus that do not involve actual policy changes. Indeed, Auerbach finds a similar increase in countercyclical responsiveness of the cyclically adjusted deficit in the United States between roughly the same two time periods, but finds no such change in policy responsiveness using explicit measures of policy changes based on data from the Congressional Budget Office (CBO). 
Evidence in favor of the impact of policy rules comes from fiscal policy differences among the individual US states. Virtually all US states have some sort of annual requirement related to budget balance, although these restrictions vary in their intensity, with some states having relatively weak rules relating only to initial policy projections and, at the other extreme, some actually requiring that each fiscal year end with a balanced budget, with measures taken within the year to offset unfolding fiscal shocks. These are self-imposed restrictions chosen independently by the individual states themselves typically more than a century ago, and therefore are arguably not simply a reflection of current fiscal policy intentions. Rather, they arose from the wishes of the states to maintain credibility and access to financial markets. ${ }^{1}$ For future reference, it should be noted that the US federal government played no role in this process. Even though these rules share some common characteristics, the similarities arose through unilateral action based on each state's self interest rather than through any type of policy coordination, explicit or even implicit.

Using differences in the stringency of state budget rules as a form of natural experiment, Poterba (1994) estimated the responses of states to incipient budget gaps, finding that states with stronger rules reacted more sharply in terms of rapid enactment of deficit-reducing policies. Moreover, these policy responses appear to represent more than just accounting changes. Using the same cross-state variation in fiscal rule stringency as a predictor of the strength of procyclical policy responses, Clemens and Miran (2012) find that such policy differences have multiplier effects on state income, an unlikely outcome unless the policy differences reflect differences in real government activity.

\footnotetext{
${ }^{1}$ See Eichengreen and von Hagen (1995).
} 
At the US federal level, there have been a series of budget regimes, each with its own set of rules, over the past few decades. However, given that these rules changed frequently, and that the changes tended to occur when meeting their conditions might have been economically or politically difficult, there is a real question whether they could have had any impact at all. Nevertheless, Auerbach (2008) finds changes in government behavior across these regimes consistent with their having some impact. For example, under the Gramm-Rudman-Hollings (GRH) legislation of the late 1980s, which specified annual budget deficits and made no allowance for cyclical conditions, explicit fiscal policy changes (measured using the CBO data described earlier) were procyclical, contrary to behavior in the years that followed. Under the Budget Enforcement Act (BEA) in place during the 1990s, which (under the so-called PAYGO rules) did not apply to realized deficits themselves but only to changes in deficits directly attributable to legislation, policy responses to both the output gap and the budget surplus were weaker than in the period after 2000, when the BEA had expired and there were no comparable budget rules in effect. At the same time, there were some behavioral responses by government to the budget rules which were clearly intended to circumvent their effects. For example, late in the 1990s, as budget surpluses accumulated and the political pressure to increase deficits increased, there was a huge increase in "emergency" discretionary spending, a spending category not subject to the BEA's discretionary spending caps (CBO 1999); much of this spending had little to do with actual emergencies.

In summary, there is mixed evidence that budget rules have real impacts, rather than just adjustments to get around the rules or simple violation of the rules altogether. How the rules arise, how (and whether) they are enforced, and how easy they are to change undoubtedly influence their effectiveness. At the same time, having an impact is not necessarily a sign of 
success, if the rules are not well designed. The US rules during the GRH regime translated into a requirement for strong procyclical policy adjustments. That these adjustments seem to have occurred during this period indicates that GRH had the impact that logically followed from the legislation, but whether this was an intended or unintended consequence is less clear.

\section{Budget Rules Don't Work if they Call for Adjustments that are Politically Unrealistic}

As mentioned above, in the late 1990s, the US Congress found a route around the cap on discretionary spending then in force by deeming a large amount of spending to be of an emergency nature. The impetus for this was the steadily improving US budgetary position. The spending caps had been put into place at the beginning of the decade, during a period when the US deficit was 4-5 percent of GDP. But by 1998, the budget had passed into surplus for the first time in several decades. Even though there had been no change in the budget rules, the underlying policy without restriction would likely have been moving toward tax reductions and spending increases, consistent with the policy feedback rules estimated by Auerbach (2003). Thus, the rules imposed an increasing adjustment relative to the unconstrained path.

Indeed, the use of so-called emergency spending in the late 1990s was followed by an even more direct rejection of the rules in 2001, when the tax cuts proposed by President George W. Bush were passed as Congress simply ignored the PAYGO rules still legally in effect. In this case, the rules were too tight given the government's perceived fiscal health, during a brief period when there was actually concern that the Fed would lose its ability to conduct openmarket operations due to an absence of government debt.

By contrast, the previous budget regime, taking the form of the deficit targets under GRH, fell because the rules were considered too right given the economy's weakness. In the fall of 1990, when the GRH target called for a reduced deficit relative to the previous year, the 
United States had entered a recession, with its deficit rising as a consequence. To avoid the budget cuts required under GRH, President George H.W. Bush and Congress scrapped GRH in favor of the BEA regime, which included budget cuts and tax increases (thereby violating Bush's "no new taxes" pledge), but of a less Draconian nature. Europe has had similar experiences under the Stability and Growth Pact, for example when the rules were modified during the 2000s in response to violations of the rules by France and Germany argued to be necessary to deal with economic conditions.

Clearly, the degree to which rules can be subverted depends on several factors, including how well they are written relative to underlying objectives (considered more fully in the next section), what penalties are specified in the event of violation, and how easily the rules can be changed, for example whether by executive regulation, simple legislation, or constitutional change.

There is no point in devoting much time to fashioning budget rules that have no effect because they are ignored or easily side-stepped. But it is also not clear that strict adherence to budget rules is desirable. If they are poorly designed, budget rules may call for actions that would reduce national welfare, as likely would have been the case for the United States in 1990, when the rules called for a very contractionary policy during recession. Even if constructed with care to avoid such obvious flaws, there is little chance that rules can anticipate every eventuality and specify the desired actions in all circumstances. The extent to which budget rules should be flexible, what penalties should be imposed if they are violated, and how these penalties should be enforced, is an important subject on which there has been too little thought. 


\section{Sensible Design of Fiscal Rules Requires a Clear Statement of Underlying Objectives}

Budget rules typically impose limits or targets on annual budget deficits and/or spending, as well on levels of debt. In some cases, there are multi-year constraints imposed, as under the US Budget Enforcement Act, which evaluated adherence to the PAYGO rules using a five-year budget window (eventually extended to ten years). These may seem reasonable, especially if one's objective is to control "excessive" accumulations of government debt, but controlling the growth of government debt is not a coherent fundamental policy objective. That is, we may design rules in an attempt to reduce the growth of government debt, but the level of government debt itself tells us nothing about societal welfare. Presumably, there is a sense that reducing debt is welfare-improving, but this outcome may sometimes be welfare-reducing, for example in a deep recession or in wartime.

As discussed in Auerbach (2009), it is useful to classify potential concerns about the national debt into three areas: intergenerational equity, economic performance, and fiscal sustainability. That is, we worry about imposing an unfair fiscal burden on future generations; about reduced economic growth due to factors like crowding out of productive investment and the disincentive effects of high future tax rates; and about the possibility that the current policy trajectory will prove unsustainable and lead to a sharp financial crisis, with associated economic disruptions that exacerbate the general economic costs of debt accumulation.

While these categories overlap to some extent, their relative importance depends on how the economy operates. For example,

1. With strong intergenerational altruism, we may worry less about the fairness of policies that shift burdens to future generations, but intergenerational linkages do nothing to undo the economic distortions of high future marginal tax rates. 
2. If the government has strong credibility, or if the country's private sector has a high saving rate and a willingness to hold domestic debt, then higher debt and deficits can be consistent with the maintenance of a stable fiscal path.

3. If countercyclical fiscal policy is productive at reducing macroeconomic fluctuations, then we may wish to allow deficit targets to reflect this fact; likewise with other potential reasons for the social value of running deficits to vary over time, including not just wars, but also high-value social investment opportunities. But the extent of flexibility allowed should also depend on the extent to which the incentives of government and society are aligned, i.e., to the extent that we can trust the government to follow the desirable path if given the flexibility to do so.

4. Whether we wish to control spending, deficits, or both depends on the extent to which either measure corresponds to the underlying economic behavior we are trying to influence. As discussed above, controls on directly measured spending may be relatively ineffective where spending can occur effectively through the tax system. But, as will be explored further below, explicit debt may be a poor measure of liabilities that will strain budgets and require future tax increases. With two imperfect measures, it is possible that rules should relate to both.

Also, the appropriate objective for government debt depends on the nature of our policy concerns. For example, the objective of generational equity, when per capita incomes are rising over time, might call for rising revenue-GDP ratios. But a steadily rising revenue-GDP ratio would lead to rising marginal tax rates and greater tax distortions than necessary if generational equity is unaffected by the policy and hence not relevant to the choice of an optimal debt path. 


\section{Cyclical Flexibility is Important, Because Countercyclical Stabilization Policy Can be Effective}

A standard argument for having budget rules that allow flexibility in times of recession is that otherwise governments will be forced into contractionary fiscal measures when deficits rise as a consequence of falling revenues and growing expenditures. The importance of such flexibility, however, depends on a number of factors.

First, if the budget rules are at the subnational level, then the stabilization function can be ceded to higher-level government. This is the standard argument in the United States against the need for increased flexibility at the state level, where budget rules typically make no provision for cyclical conditions.

Second, it matters how much of a difference countercyclical policy can make. Estimates of fiscal multipliers vary, and at least some suggest that multipliers are small. However, recent research for the United States and OECD countries, allowing multipliers to vary with business cycle conditions, suggests a strong difference in effects in recession and expansion, with much larger multipliers (Auerbach and Gorodnichenko, 2012a, 2012b).

Third, the effectiveness of fiscal policy may depend on fiscal conditions. Many papers, including the recent one by Alesina et al. (2012), have suggested that fiscal consolidations, undertaken when countries face fiscal stress, may have relatively minor negative effects on aggregate activity, especially if the deficit reductions occur through cuts in government expenditures. Indeed, consistent with this view, Auerbach and Gorodnichenko (2012b) find for the OECD sample that government spending multipliers in recession, though on average quite high, are smaller for policies undertaken with high debt-GDP ratios. Thus, although more research is needed on this important question, there is at least some evidence that budget-rule 
flexibility may be less important in precisely the circumstances where such rules are likely to bind, i.e., when a country faces a serious fiscal imbalance.

\section{The Rationale is Weak for Coordinated Budget Rules within a Currency Union}

There has been considerable discussion since the onset of the financial crisis in Europe about the performance of the Stability and Growth Pact and the need to improve the functioning of Eurozone budget rules. Here, however, there is a clear case for some serious thought regarding the underlying objectives of budget rules. As argued in Auerbach (2011a), the rationale for having central coordination of budget rules within a currency union like the Eurozone is unclear, and many of the apparent arguments are weak.

One standard argument is that, within a currency union, fiscal policy coordination is needed to limit cross-border spillovers of policy effects, because such spillovers cannot be neutralized by individual countries through the use of monetary or exchange rate policies. But this argument applies to any economic shocks, not just those attributable to fiscal policy, and indeed could constitute an argument for greater fiscal flexibility, so that countries can act more forcefully to use fiscal policy to offset other economic shocks.

Another common argument is the need to avoid soft budget constraints. Economic integration within a currency union may signal other connections among countries, in particular social cohesion and interaction. If residents of one country in a currency union care about the well-being of those in another, then this connection might provide another rationale for common budget rules, based on the familiar problem of the Samaritan's dilemma. However, based on homogeneity and social cohesion, Europe appears much less susceptible to the Samaritan's dilemma than does the United States, where there is no coordination of state-level budget rules and no apparent temptation for bailouts. On the other hand, the United States also has in place a 
number of federal institutions, most notably the federal tax system, that automatically cushion shocks to individual income and hence also to aggregate income in any particular state or region and thus lessen the impetus for further action in response to a shock. Such federal institutions function not only as shock-absorbers; they also provide persistent transfers among regions, with wealthy states and regions providing considerable support to those that are poorer. This weakens the perceived need to intervene to bail out governments. Although there has been some movement toward a stronger central fiscal authority in Europe, it seems very unlikely that transfers on a scale that exist in the United States could develop. But this is precisely because of differences in the degree of social cohesion, and therefore hardly makes a stronger case for the need to avoid the Samaritan's dilemma.

Cross-border financial exposure with the Eurozone, for which there is nothing comparable in the United States, does help explain why other Euro area countries would have been concerned about the consequences at home of a debt crisis in other countries. But explanations for bailouts and the need for budget rule enforcement based on cross-border exposure are typically circular in nature, relying on the argument that individual country debts are viewed as implicitly convertible. It is clear from the convergence of interest rates as countries joined the Eurozone that something like implicit convertibility was assumed, but this is not necessarily a good assumption for the future.

One possible argument in favor of fiscal rule coordination comes from another setting in which there is a central imposition of rules that ought to be in the countries' self interest, international trade. Especially for small countries that can have little impact on their terms of trade, the arguments for free trade are compelling, yet much effort has been devoted to the promulgation and enforcement of free-trade agreements. One explanation for such agreements is 
that they serve as a counterweight to the pressures of domestic interest-group politics. Likewise, it may be that the governments of some countries need external support to implement fiscal policies that are in their countries' overall interests, but not in the interests of some powerful interest groups. Although this argument makes sense, it is rarely offered in justification of fiscal rule coordination.

In short, common fiscal rules in a currency union appear to be a solution in search of a problem.

\section{Current Debt and Deficits are Poor Indicators of Fiscal Stress, Particular with} Population Aging and Age-Based Fiscal Policies

Budget rules usually relate to current values of debt and deficits. To the extent that they are forward-looking, they may include a projected multi-year trajectory as well. But, given the growing commitments of unfunded government programs, particularly those that are age-based, such constraints miss much of the fiscal challenge being faced currently by a typical developed country with an aging population.

To understand the problem, it is useful to consider the government's intertemporal budget constraint, which says that the stock of government debt carried over from the past year $\left(B_{t-1}\right)$ plus the present value of primary deficits $(D s)$ must equal zero:

$$
B_{t-1}+\sum_{s=t}^{\infty}(1+r)^{-(s-t+1)} D_{s}=0
$$

where $r$ is the relevant interest rate, here assumed for convenience to be constant. To the extent that this budget constraint is not satisfied, it is useful to decompose the sources of the gap in the following way: (1) past deficits, as accounted for by the accumulated stock of debt; (2) current deficits, if held constant over time, in terms of the ratio of primary deficits to GDP; and (3) the 
projected growth of deficits as a share of GDP, relative to the present. Budget rules focus primarily on the first two of these components, but very little on the third. Unfortunately, it is the third component that is the most important source of the fiscal gap - the imbalance in equation (1) under current policies - for most developed countries. That is, deficits are projected to grow substantially faster than GDP under current policy trajectories.

Figure 1, adapted from Auerbach (2011b), helps illustrate this point. For several developed countries, the figure shows the fiscal gap over the 50-year period 2011-2060, estimated using a variety of data sources described in detail there. The fiscal gap is defined as the annual reduction in the primary deficit as a share of GDP, say $\Delta$, that would be needed to keep a country's publicly held debt-GDP ratio at the end of the period equal to its initial debtGDP ratio; that is,

$$
\Delta=\frac{B_{t-1}-(1+r)^{-(T-t)} B_{t-1} \frac{Y_{T+1}}{Y t}+\sum_{s=t}^{T}(1+r)^{-(s-t+1)} D_{S}}{\sum_{s=t}^{T}(1+r)^{-(s-t+1)} Y_{S}}
$$

where $Y_{t}$ is GDP in year $t$ and $T$ is the terminal year (in this case 2060). Note that, for the infinite horizon $(T \rightarrow \infty), \Delta$ is the change in primary deficits as a share of GDP needed to satisfy the government's intertemporal budget constraint given in (1).

The figure shows overall fiscal gaps for a group of countries, represented by the first set of bars. The second set of bars shows what fiscal gaps would be if initial outstanding debt were set to zero; the difference between the first two sets of bars shows how much of the gap is attributable to past deficits, in the above decomposition. The third set of bars, which holds the growth in health care and public pension spending at the rate of GDP growth, indicates roughly what fiscal gaps would be if their third source, the growth of future deficits relative to GDP, 
were eliminated; comparing the first and third bars indicates the importance of this factor. It is quite clear from the figure that, for most countries, the third factor is the most important. That is, even if the need to service existing national debt were eliminated and the path of future primary deficits started at zero, the projected growth in primary deficits would leave most countries in need of substantial fiscal adjustments.

Another way to express the size of age-based unfunded liabilities is by capitalizing them and comparing them to outstanding explicit liabilities. For the United States, for example, by one measure the unfunded liability of the Social Security system, the present value of benefits less taxes less the existing trust fund balance, was $\$ 20.5$ trillion at the beginning of 2012 (Social Security Trustees, 2012, Table IV.B7) ${ }^{2}$ this was roughly twice the publicly held stock of national debt at that time (\$10.4 trillion). As large as this measure of the Social Security implicit liability is, it pales in comparison to what one would calculate using a similar methodology for the major U.S. public health care spending programs, Medicare and Medicaid. Even under the most favorable estimates, for example, Medicare's infinite horizon unfunded liability at the beginning of 2012 was nearly $\$ 43$ trillion. ${ }^{3}$ Thus, for the United States, the unfunded implicit liabilities of two major entitlement programs are roughly six times the stock of publicly held national debt. Yet, because standard methods of government accounting ignore these liabilities,

\footnotetext{
${ }^{2}$ This measure is sometimes referred to as the "open group" implicit liability, which takes account of all future cohorts. An alternative measure, equal to $\$ 21.6$ trillion, is the "closed group" implicit liability, calculated as the present value cost of paying benefits to those already retired or in the work force in excess of the present value of taxes that this same group of individuals will pay into the system, and also net of the system's trust fund balance. The small difference between the closed-group and open-group measures indicates that under current policy future generations would receive benefits with a slightly lower present value than their taxes.

${ }^{3}$ According to the 2012 Medicare Trustees Report, over the infinite horizon general revenue contributions - funding from sources over and above the programs' dedicated revenues - of $\$ 23.7$ trillion will be needed to cover expenses for Medicare Part B (supplementary medical insurance; see Table III.C11) and another \$14.3 trillion will be needed to cover Medicare Part D (prescription drug insurance; see Table III.D8). According to these same projections, the remaining component of Medicare, Part A (hospital insurance; see Table III.B11) has an infinite-horizon unfunded liability of $\$ 4.8$ trillion. Moreover, these large numbers assume the successful enforcement of the reductions in reimbursement rates as called for by the 2010 Affordable Care Act. Alternative projections put the costs of Medicare higher.
} 
they show up only over time in terms of increases in primary deficits, as indicated in Figure 1.

Budget rules that do not reflect this reality are missing most of the fiscal problem.

\section{The Inflation Tax is an Ineffective Tool for Dealing with Today's Fiscal Problems}

One traditional concern about large budget deficits is that they may lead to inflation. There is more than one potential channel through which this link might occur. The most straightforward is situation in which monetary policy accommodates fiscal policy, which may lead to an increase in seignorage through money creation when deficits increase (Sargent and Wallace, 1981). Another is the Fiscal Theory of the Price Level (FTPL; see, e.g., Leeper, 1991), which relates closely to the government's intertemporal budget constraint in expression (1). Under the FTPL, a passive fiscal policy, i.e., one that is not projected to respond to fiscal imbalances in a manner to ensure that expression (1) is satisfied, can induce jumps in the price level that satisfy (1) by reducing the real value of nominal liabilities, $B_{t-1}$. These two models differ in the role played by the monetary authority in influencing the price level, but, in both settings, increases in the price level are induced by fiscal imbalances and, in turn, contribute to reducing these imbalances through seignorage from money creation and the erosion in value of the government's outstanding liabilities.

Views may differ about whether inflation has any attraction as a means of dealing with fiscal imbalances; presumably its attractiveness depends on whether the alternative is some more standard fiscal adjustment or just explicit default. But a key point in the current environment is that that inflation is much less powerful as a potential tool for dealing with fiscal imbalances, because so much of these imbalances arise from the very implicit liabilities just discussed. These liabilities are not only implicit, but they are typically also price-level indexed. In the United States, for example, public pensions are explicitly indexed to the price level, while publicly 
provided medical care is essentially a guarantee of a certain quantity bundle of goods and services, rather than a nominal expenditure amount. Thus, as prices rise, their real values are essentially unaffected. Given the previous discussion about the relative unimportance of existing debt as a source of fiscal imbalances, this means that price level adjustments should not be viewed as particularly relevant channel for fiscal adjustments. This does not necessarily mean that there will be no linkage between deficits and inflation, but simply that any such inflation will lack the positive budget effects with which it has traditionally been associated. Improvements in the government's fiscal position will have to occur in other ways.

\section{Budget Accounting Leaves Considerable Flexibility Regarding Reported Current and}

\section{Future Deficits}

As discussed above, projections of current fiscal policies for the United States and other developed countries indicate that implicit liabilities account for the biggest component of fiscal gaps. This suggests that rules that do not somehow take implicit liabilities into account can be of limited effectiveness and promoting fiscal sustainability. How to integrate implicit and explicit liabilities within a budget rule is challenging, though, and one reason for this is that governments have considerable flexibility regarding how they account for inflows and outflows. In principle, for example, a public pension system could be recast as a system of borrowing and lending combined with transfer payments to (or taxes on) the elderly, with no change in cash flows or their distribution among individuals but a conversion of implicit debt into explicit debt. Moreover, equivalences like this can be found throughout the government budget, for example with respect to the timing of taxes (see Auerbach and Kotlikoff, 1987, Chapter 7).

Indeed, there are some clear examples of policy changes aimed primarily at changing measured deficits without affecting underlying policy. In 1997, for example, Congress 
introduced a tax-favored saving scheme (the Roth Individual Retirement Account, or Roth IRA) that exempted returns from taxation, as an alternative to an existing scheme (the traditional IRA) that provided a tax deduction for contributions but then taxed all withdrawals of interest and principal. The legislation also offered tax incentives to switch funds from traditional IRAs to Roth IRAs. While the two schemes are economically similar (and equivalent when tax rates are constant over time), the timing of tax revenues differs between the two. The Roth IRA generates revenue losses of comparable present value as the traditional IRA, but these revenue losses occur later. Switches of funds from traditional IRAs into Roth IRAs actually increase short-run revenue by speeding up the payment of taxes on withdrawals from the traditional IRAs. Thus, the introduction of the Roth IRA was estimated to increase tax revenue over the budget window, even while representing a permanent reduction in the present value of tax revenue, because of the tax incentives provided for switching.

Even where accounting changes may not be the primary motivation for a change in policy, their incidental occurrence can still have important effects. For example, in 2005, President George W. Bush proposed a system of partial privatization for the US Social Security old-age pension system. Under the proposal, individual workers could have redirected a portion of their payroll taxes to individual retirement saving accounts under their own control. In exchange for the funds placed in these accounts, the workers would have had their future benefits reduced, by roughly the same amount in present value. At the same time, the government would have issued bonds to pay the benefits of current retirees, to replace the funds diverted to the individual accounts. The motivation for this proposal was to increase the share of retirement income provided through private asset accumulation, but the proposal also had the effect of substituting explicit liabilities for implicit ones, reducing the present value of future Social 
Security benefits by roughly the amount of the new debt being issued. Yet a major concern among some opponents of the proposal was that it would vastly increase the national debt and worsen the US government's fiscal position.

\section{Budget Deficits Provide an Inadequate Measure of the Generational Consequences of}

\section{Fiscal Policy}

Considering the path of deficits rather than just the current one, adjusting for implicit liabilities, and recognizing the underlying equivalence of policies with different deficit paths all contribute to gaining a better understanding of the sustainability of a given fiscal trajectory. But there is no simple adjustment or measure based on current and future deficits that provides a clear picture of the generational incidence of fiscal policy, because for any path of deficits, even corrected for the presence of implicit liabilities, there may be very different underlying patterns of generational incidence. To see the problem, consider the following example, taken from Auerbach (2009).

Suppose that the government is considering three changes in its existing unfunded public pension system, which we will assume to be run with annual cash-flow balance and financed by payroll taxes. Table 1 summarizes these three policy changes and their various effects. The first policy would increase the size of the pension system by increasing payroll taxes beginning in five years and increasing the subsequent benefits of those paying higher taxes by an amount equal in present value. The second policy would reduce pension benefits for all recipients beginning in five years, by the same aggregate annual amount as the tax increase under the first policy, with no change in payroll taxes. The third policy would begin reducing benefits starting in twenty years, with the same present value reduction in benefits to current generations as the second plan, i.e., reducing benefits by less initially but eventually by a greater amount. 
None of these plans would have any impact on the current national debt or deficit, as shown in the column 1 of the table. The first two plans would also have the same impact on the annual budget deficit five years out and for several years in the future and hence the same trajectory of explicit national debt (column 2), providing the picture that both eventually reduce the national debt. But these two plans would have fundamentally different economic consequences.

The first policy has no impact on current generations, old or young (columns 4 and 5) for it would maintain the benefits of older generations and would increase benefits in line with taxes for younger generations. Hence, despite its reducing the budget deficit over the short term, this policy would have no impact on the system's implicit liabilities to existing generations (i.e., the closed-group liabilities, column 3) and hence no change in the debt being passed on to future generations (column 6).

The second policy, by reducing benefits of current generations, both old and young, would reduce the burden being passed on to future generations. Including the pension system's implicit liabilities to current generations in a measure of national debt would account for the difference between the first and second policy, recognizing that the first policy results in higher implicit liabilities and higher future marginal tax rates than the second.

The third policy has no impact on the budget deficit, even over the first twenty years but, like the second policy, it reduces the burden being passed to future generations. Accounting for implicit liabilities to existing generations reflects this reduction accurately. But this fiscal policy has different effects on existing generations than does the second policy, even though they produce the same reduction in implicit liabilities. By delaying implementation, it allows current retirees to escape benefit cuts, which then must fall harder on younger generations, given the 
assumption that the benefit cuts have the same present-value impact on current generations under the two policies. The liabilities to existing generations are the same in the aggregate, but the distribution among existing generations differs, potentially significantly. The differences in generational burdens can also have macroeconomic consequences if, for example, the consumption patterns and marginal propensities to consume differ between the old and the young.

An alternative construct that would reflect the differences in these three policies is generational accounts, as described in Auerbach, Gokhale and Kotlikoff (1991) and elsewhere. Generational accounts distribute the burdens and benefits of annual taxes and spending to different generations based on assumed patterns of incidence. Generational accounts provide measures that have a much closer connection to the underlying objectives of government policy than either adjusted or unadjusted measures of deficits.

\section{Budget Rules Should be Forward-Looking, but Should Discount the Future}

A general theme of the previous discussion is that it is important to take account of the future path of deficits, either directly or through the calculation of implicit liabilities or generational accounts. Budget rules typically do not do this over more than a very short horizon, so it is useful to consider what some of the complications might be.

One potential argument is the additional information required for the calculation, and the considerable uncertainty associated with projections deep into the future. As calculations of implicit liabilities and generational accounts are now fairly standard, the first part of this argument is not very convincing. As to the second part, it is of course true that our projections of the future carry very large confidence intervals. But this is not an argument for ignoring the future consequences of current policy. 
A second argument against integrating implicit liabilities with current liabilities is that future benefits do not represent legal claims in the same way that explicit government debt does. It is an essentially empirical question whether the government is likely to meet its future liabilities, and if so to what extent. The same argument applies to the construction of generational accounts, which typically allocate all future taxes and spending along the assumed policy trajectory, automatically giving the same weight to all components of future taxes and spending, regardless of the strength of the commitments associated with these elements of fiscal policy.

One potential response to this second argument is to integrate future taxes and spending into calculations of the government's fiscal trajectory, but to discount future policy measures (beyond normal discounting based on the interest rate) when estimating the fiscal effects of policy changes. For example, a policy of raising spending today and reducing it far in the future by the same present value would be counted as a net increase in spending and a worsening of the government's fiscal position, because the likelihood of the future policy action would be discounted further. A budget rule of this type can be derived from a model in which government commitment to future actions is limited by prospective changes in government control (Auerbach, 2006). It also has the feature of reducing inherent tendencies of the political process to shift fiscal liabilities to future generations.

\section{Conclusions}

Budget rules can have an impact, particularly if they enforce outcomes that are not too far in political terms from unrestricted choices. But what fiscal rules should look like, and in what circumstances they should exist, are more difficult questions to answer. Simple budget rules based on existing liabilities and current and near-term budget deficits require some flexibility to 
deal with cyclical concerns, at and the same time fall far short of dealing with the longer-term budget issues that are the most critical for a large number of leading economies. Taking a longer-term perspective on policy is important, but becomes a very complex task once one accounts for forecast uncertainty and the inadequacy of standard budget measures as representations of underlying policy objectives. In light of these complexities, we stand at a point where practice has proceeded beyond what theory and evidence can justify; where there is pressure to modify and strengthen budget rules even where the best way to do so, and the benefits of doing so, are unknown.

In this environment, the recent trend toward the establishment of independent budget agencies, such as Sweden's Fiscal Policy Council and the UK's Office of Budget Responsibility, charged with the task of monitoring and evaluating fiscal policy decisions, is a salutary one. There are different models for what they should do, but such agencies have the capacity to evaluate policies using more sophisticated criteria than would be practical in the construction of budget rules. There is a trade-off, of course, in that such appointed and independent agencies lack the enforcement power at least officially vested in budget rules. But this drawback is more superficial than real in comparison to budget rules that exist but may not be enforceable, or may enforce bad outcomes. Also, more than simple budget rules, independent fiscal entities can expose gaps in logic and provide additional support for needed changes in fiscal policy that may require implementation over a period of years. 


\section{References}

Alesina, Alberto, Carlo Favero, and Francesco Giavazzi, 2012, "The Output Effect of Fiscal Consolidations," August.

Auerbach, Alan J., 2003, "Is There a Role for Discretionary Fiscal Policy?" in Federal Reserve Bank of Kansas City, Rethinking Stabilization Policy, 109-150.

Auerbach, Alan J., 2006, "Budget Windows, Sunsets, and Fiscal Control," Journal of Public Economics, January, 87-100.

Auerbach, Alan J., 2008, "Federal Budget Rules: The U.S. Experience," Swedish Economic Policy Review, Spring, 57-82.

Auerbach, Alan J., 2009, "Long-Term Objectives for Government Debt," FinanzArchiv 65, December, 472-501.

Auerbach, Alan J., 2011a, "Fiscal Institutions for a Currency Union," paper presented at a conference on Fiscal and Monetary Policy Challenges in the Short and Long Run, sponsored by the Deutsche Bundesbank and the Banque de France, Hamburg, May 19-20.

Auerbach, Alan J., 2011b, "Long-Term Fiscal Sustainability in Major Economies," Bank for International Settlements Working Paper No. 361, November.

Auerbach, Alan J., Jagadeesh Gokhale, and Laurence J. Kotlikoff, 1991, "Generational Accounts: A Meaningful Alternative to Deficit Accounting," in D. Bradford, ed., Tax Policy and the Economy 5, 55-110.

Auerbach, Alan J., and Yuriy Gorodnichenko, 2012a "Measuring the Output Responses to Fiscal Policy," American Economic Journal: Economic Policy 4, May, 1-27.

Auerbach, Alan J., and Yuriy Gorodnichenko, 2012b "Fiscal Multipliers in Recession and Expansion," in A. Alesina and F. Giavazzi, eds. Fiscal Policy after the Financial Crisis, forthcoming

Auerbach, Alan J., and Laurence J. Kotlikoff, 1987, Dynamic Fiscal Policy, Cambridge: Cambridge University Press.

Board of Trustees, Federal Hospital Insurance and Federal Supplemental Medical Insurance Trust Funds, 2012, The 2012 Annual Report of the Board of Trustees of the Federal Hospital Insurance and Federal Supplementary Medical Insurance Trust Funds. Federal Hospital Insurance and Federal Supplemental Medical Insurance Trust Funds, Washington, DC, April 23.

Board of Trustees, Federal Old-Age and Survivors Insurance and Disability Insurance Trust Funds, 2012, The 2012 Annual Report of the Board of Trustees of the Federal Old-Age and 
Survivors Insurance and Federal Disability Insurance Trust Funds. Federal Old-Age and Survivors Insurance and Disability Insurance Trust Funds, Washington, DC, April 23.

Clemens, Jeffrey P. and Stephen I. Miran, 2012, "Fiscal Policy Multipliers on Sub-National Government Spending," American Economic Journal: Economic Policy 4, 46-68.

Congressional Budget Office, 1999, Emergency Spending Under the Budget Enforcement Act: An Update, U.S. Government Printing Office, Washington.

Eichengreen, Barry and von Hagen, Jürgen, 1995, "Fiscal Policy and Monetary Union: Federalism, Fiscal Restrictions and the No-Bailout Rule," CEPR Discussion Paper No. 1247, September.

Galí, Jordi and Roberto Perotti, 2003, "Fiscal Policy And Monetary Integration In Europe," Economic Policy 18, October, 533-572.

Leeper, Eric, 1991, 'Equilibria Under 'Active' and 'Passive' Monetary Policies," Journal of Monetary Economics 27, 129-147.

Poterba, James, 1994, "State Responses to Fiscal Crises: The Effects of Budgetary Institutions and Politics," Journal of Political Economy 102, August, 799-821.

Sargent, Thomas J. and Neil Wallace, 1981, "Some Unpleasant Monetarist Arithmetic," Federal Reserve Bank of Minneapolis Quarterly Review 5, Fall, 1-17. 
Figure 1. Fiscal Gaps through 2060

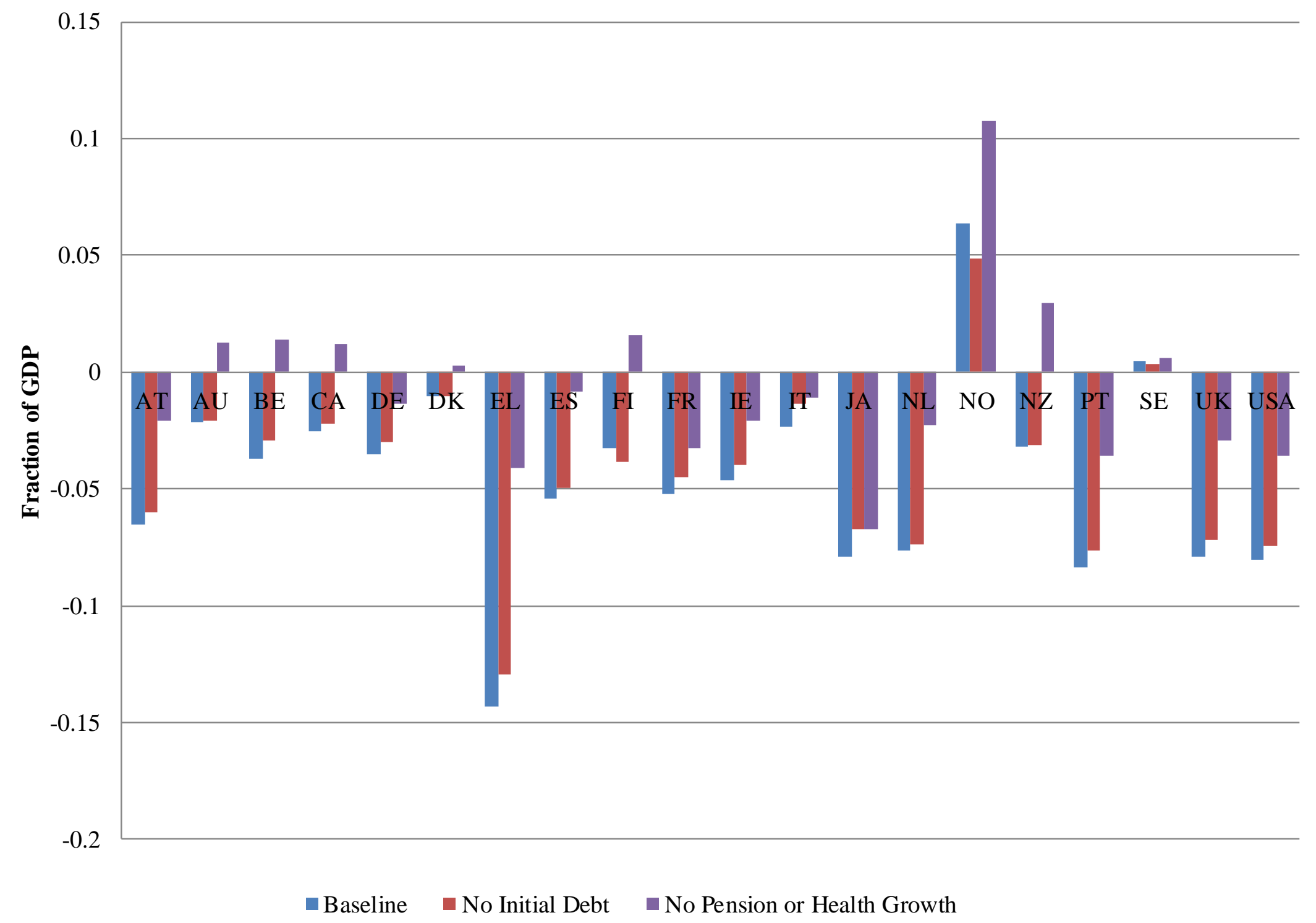


Table 1. The Impact of Changes in a Public Pension System

\begin{tabular}{|c|c|c|c|c|c|c|}
\hline \multirow[b]{2}{*}{ Experiment } & \multicolumn{6}{|c|}{ Impact on: } \\
\hline & $\begin{array}{c}(1) \\
\text { Current } \\
\text { Debt and } \\
\text { Deficit }\end{array}$ & $\begin{array}{c}\text { (2) } \\
\text { Short-Term } \\
\text { Debt and } \\
\text { Deficit }\end{array}$ & $\begin{array}{c}(3) \\
\text { Implicit } \\
\text { Liabilities }\end{array}$ & $\begin{array}{c}\text { (4) } \\
\text { Older } \\
\text { Generations }\end{array}$ & $\begin{array}{c}(5) \\
\text { Younger } \\
\text { Generations }\end{array}$ & $\begin{array}{c}\text { (6) } \\
\text { Future } \\
\text { Generations }\end{array}$ \\
\hline $\begin{array}{l}\text { 1. Increase payroll taxes and } \\
\text { associated benefits by } \\
\text { same present value, } \\
\text { starting in five years }\end{array}$ & 0 & $\downarrow$ & 0 & 0 & 0 & 0 \\
\hline $\begin{array}{l}\text { 2. Reduce future benefits } \\
\text { following same annual } \\
\text { pattern as tax increases in } \\
\text { experiment \#1 }\end{array}$ & 0 & $\downarrow$ & $\downarrow$ & $\downarrow$ & $\downarrow$ & $\uparrow$ \\
\hline $\begin{array}{l}\text { 3. Reduce future benefits by } \\
\text { the same present value as } \\
\text { in experiment } \# 2 \text {, starting } \\
\text { in } 20 \text { years }\end{array}$ & 0 & 0 & $\downarrow$ & 0 & $\begin{array}{l}\downarrow \\
\downarrow\end{array}$ & $\uparrow$ \\
\hline
\end{tabular}

